\title{
Windstorms as mediator of soil nematode community changes: Evidence from European spruce forest
}

\author{
M. RENČO*, A. ČEREVKOVÁ \\ Institute of Parasitology SAS, Department of Environmental and Plant Parasitology, Hlinkova 3, 04001 Košice, Slovak Republic, \\ *Email: renco@saske.sk
}

Article info

Received August 25, 2016 Accepted December 15, 2016

\begin{abstract}
Summary
Nematode communities in a Norway spruce forest in High Tatra National Park, Slovakia were monitored for the period of several years (2006 and 2013). Unfortunately, in May 2014 natural windstorm damaged the forest. This disastrous event, together with preliminary obtained results allowed us to compare the direct impact of windstorm damage of forest habitat on soil nematode assemblages. The forest destruction by windstorm had a significant effect on the total nematode abundance, the abundance of omnivores and herbivores, as well as the nematode species diversity. The most dominant species, representing $55 \%$ of the total nematode fauna, in the plot studied were Acrobeloides nanus followed by Malenchus exiguus, Filenchus vulgaris, Plectus communis, Plectus parvus and Tylencholaimus mirabilis. The abundance of bacterivorous significantly increased after the windstorm, meanwhile the abundance of omnivores, fungivores, and herbivores ectoparasites and epidermal/root hair feeders showed an opposite trend. Of the evaluative indicators, Shannon species diversity (H'spp), maturity index (MI), maturity index 2-5 (MI2-5), sigma maturity index ( $\mathrm{MI}$ ), enrichment index (EI) and structure index (SI) decreased significantly after windstorm. The EI and SI indexes characterized soil ecosystems before windstorm (2006 - 2013) as maturing with low or moderate disturbance, but soil ecosystems shortly after the windstorm (2014) were degraded and nutrient depleted. This also corresponded with graphical display of metabolic footprints characteristics of soil food web. Overall, the nematode communities differed significantly before and after forest damage. These results suggest the role of nematode communities as indicators of environment condition quality or its disruption.
\end{abstract}

Keywords: ecosystem; diversity indices; forest devastation; storm; nematode-fauna; metabolic footprints

\section{Introduction}

Norway spruce is the second most prevalent tree species in Slovakia and forms about $17 \%$ of the forest nationwide. However, the current condition of these spruce forests is in decline due to bark-beetles attack, pathogenic fungi, loss of vitality due to climatic changes and weather conditions including windstorms events.
Wind disasters can suddenly affect large areas, up to thousands of hectares per event, and possibly are the most important event in terms of the effect on forest composition and dynamics (Everham \& Brokaw, 1996). Therefore, the understanding and prediction of ways by which intense windstorms affect ecosystem structure, composition and function is important for the successful forest management.

\footnotetext{
$\overline{{ }^{*} \text { - corresponding author }}$
} 
Large or smaller windstorm events are appearing in the forest ecosystems periodically. In the territory of the Slovak Republic $1.5 \times 10^{6} \mathrm{~m}^{3}$ of timber in 1996; $1.0 \times 10^{6} \mathrm{~m}^{3}$ of timber in 1999 and $1.5 \times 10^{6} \mathrm{~m}^{3}$ of timber in 2002 were damaged during the storms. However, on November 19, 2004 (Gubka et al., 2014) the largest windstorm event ever destroyed $5.3 \times 10^{6} \mathrm{~m}^{3}$ of mostly natural/semi natural Norway spruce forest in High Tatra National Park. Most of the broken and uprooted trees were completely removed from the affected areas in the following months, and $600 \times 10^{3} \mathrm{~m}^{3}$ of the intact fallen trees were left in their natural succession. A wildfire in May 2005 burned approximately 250 hectares that had been cleared after the storm in 2004. Several permanent research plots were established in the damaged areas by the park administration. The purpose was to set up a long-term study analysing the impact of these natural catastrophes on the spruce forest ecosystem and stage of ecosystem recovery under different management and fire (Fleischer, 2008).

Regrettably, another large windstorm in May 2014 ten years after the first storm damaged again the forests in the High Tatra Mountains ( 135 thousands $\mathrm{m}^{3}$ of timber), including the site that had been monitored since 2006 as a control plot. Moreover, this windstorm damaged about 30 ha of young forest which grew up after the storm in 2004 as well as deciduous forests (Gubka et al., 2014). The destruction of the control plot by storm in 2014 and availability of collected data from this plot since 2006 to 2013 provided an ideal opportunity to investigate direct effect of windstorm on ecosystems changes utilising soil nematodes as bioindicators.

Various species of soil dwellers (nematodes, collembolans, mites etc.) have been used as biological indicators of soil health and sustainability and for monitoring the changes in soil environment by various spatial and temporal scales (Lindenmayer, 1999; Doran \& Zeiss, 2000), but nematodes are also used frequently (Bongers 1990; Yeates et al., 1993; Ferris et al., 2001). Nematode densities can reach several million individuals per square metre and forest nematode communities often comprise more than 100 species (Yeates et al., 2000). Species richness is generally higher in undisturbed than disturbed ecosystems (Neher et al., 2005; Čerevková \& Renčo, 2009).

In previous study realized after the 2004 storm we monitored changes of soil nematode communities in several spruce forest plots after the event nevertheless that nematode assemblage was not investigated in destroyed plots before windstorm (Čerevková \& Renčo, 2009). Here, we investigate direct impact of forest destruction by 2014 storm on nematode communities in plot that has been monitored since 2006 as intact control forest. The primary aims of this study were to $1 /$ check whether the soil nematode communities were sensitive to spruce forest devastation; 2/ compare the nematode community composition between undisturbed and disturbed forest soils; $3 /$ analyse and compare the impact of windstorms on nematode communities, abundance, species numbers and diversity, composite indices, metabolic footprints and nematode biomass. We assumed that changes in nematode assemblages will be similar to those recorded after windstorm in 2004, and thus acquire direct confirmation, that nematodes can serve as valuable bioindicators for ecosystem disturbance.

\section{Materials and Methods}

\section{Characteristics of the study sites and soil sampling method}

Study has been carried out in the natural spruce forest in the High Tatra Mountains. Stand was covered with a 120 -year-old stand of $80 \%$ Picea abies (L.) Karst, and $20 \%$ Larix decidua Mill. The ground vegetation was rich in mosses, spruce needles, Vaccinium myrtillus L., and Oxalis acetosella L. and in open areas by Avenella flexuosa (L.) Drejer and Calamagrostis villosa (Chaix), J. F. Gmel. The botanical characterization of the study area has been described by Šoltés et al. (2010). The entire area is characterised by cold climate with an average annual temperature of $5.3^{\circ} \mathrm{C}$ and annual rain precipitation of about $833 \mathrm{~mm}$ (Fleischer, 2008). The dominant soil type is a Dystric Cambisol developed on glacial moraine deposits with an above ground humus layer $12 \mathrm{~cm}$ thick on the study plot, with $\mathrm{pH} 3.2$ - 3.3; for more detailed characteristic see (Renčo et al., 2015).

Soil samples were collected between October 2006 and 2013, when forest was undisturbed and from the same plot in October 2014 after the large windstorm which took place in May 2014 (disturbed forest). All fallen trees were laid down in area at the time of soil samples collection (October 2014).

A quadrant soil sampling method was used. Five quadrants (10 $x 10 \mathrm{~m}$ ) were marked within the plot area. From each quadrant $\left(100 \mathrm{~m}^{2}\right)$ five sub-samples were collected. One from each corner and one from the centre, to obtain five representative composite soil samples $(1 \mathrm{~kg})$. Sampling was conducted using a garden trowel up to the depth of $10 \mathrm{~cm}$ including litter layer. The five composite soil samples were preserved in plastic bags and maintained in refrigerator at $5^{\circ} \mathrm{C}$ until processing. For laboratory processing, each sample was homogenized by soft hand mixing. A total of 15 representative soil samples were collected and analysed, five in 2006 and 2013 (before windstorm) and five in 2014.

\section{Nematode extraction and identification}

Each composite sample was homogenized by gentle hand mixing, and $100 \mathrm{~g}$ of soil were then soaked with $1 \mathrm{I}$ of tap water for 30 - 60 min and processed by Cobb sieving and decanting (Cobb, 1918) followed by a modified Baermann's technique (van Benzojen, 2006). Nematodes were extracted from the aqueous soil suspensions using a set of two cotton-propylene filters. One or two filter trays were used per sample to prevent material from exceeding $0.5 \mathrm{~cm}$ in depth above the filter. Subsamples were collected after subsequent extraction for $48 \mathrm{~h}$ at room temperature. The aqueous suspensions were examined under a stereomicroscope (Leica S8APO, magnification 20, 40, 60, 80x). The excessive water was removed, and the nematodes were fixed with a hot 99:1 solution of $4 \%$ formaldehyde: pure glycerol (Seinhorst, 1962). 


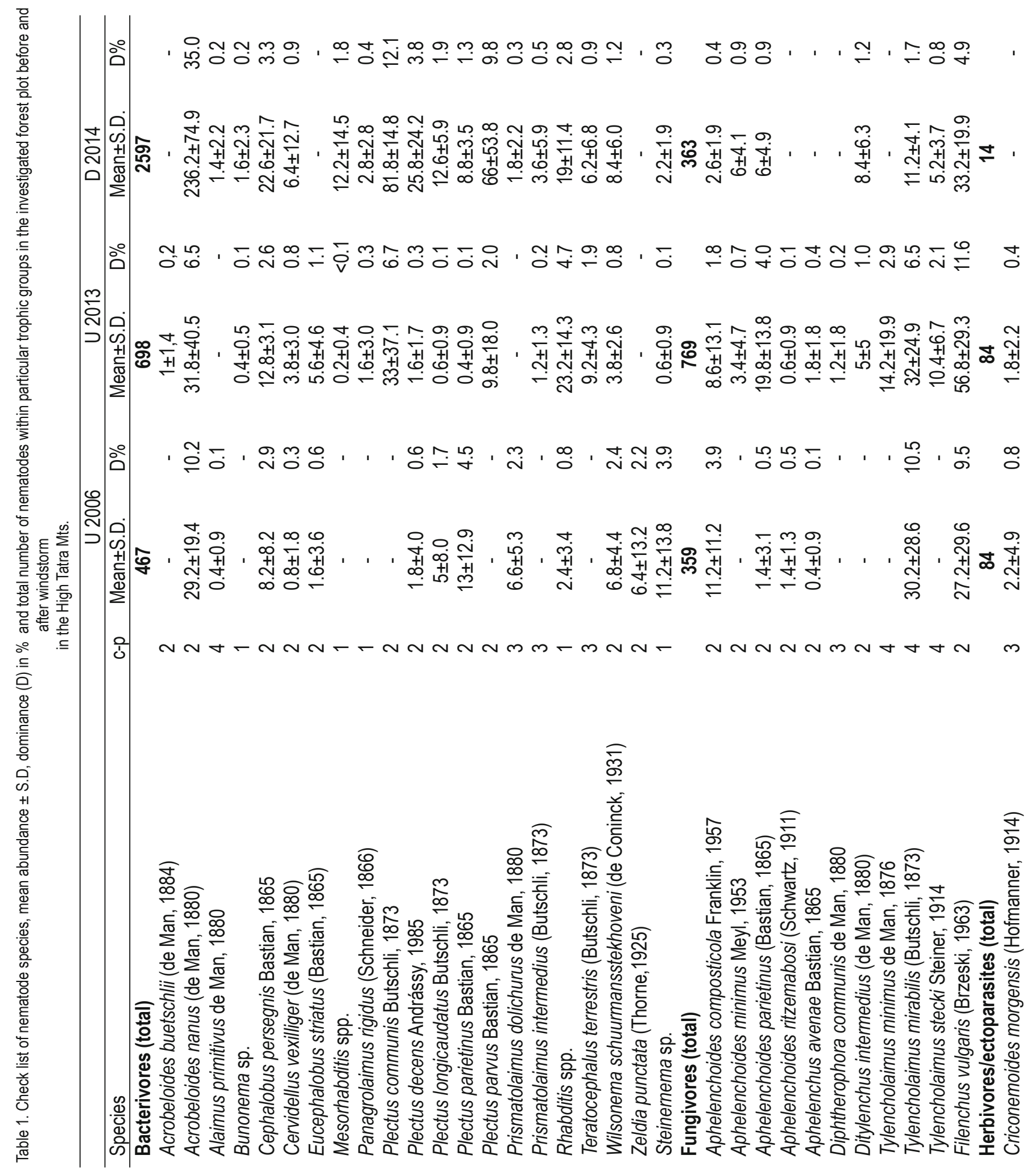




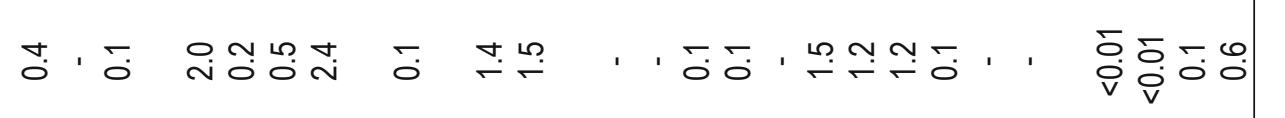

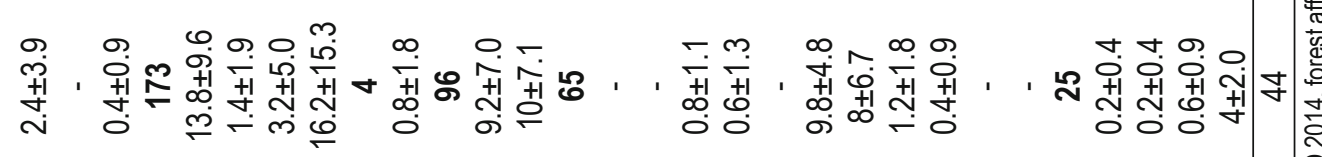

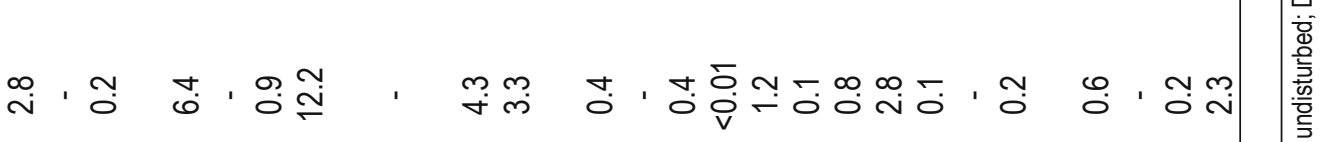

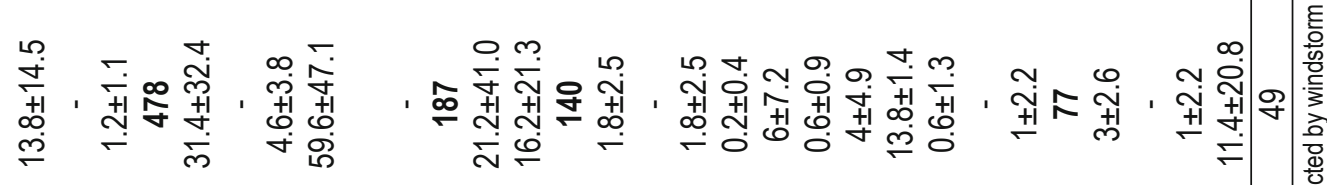

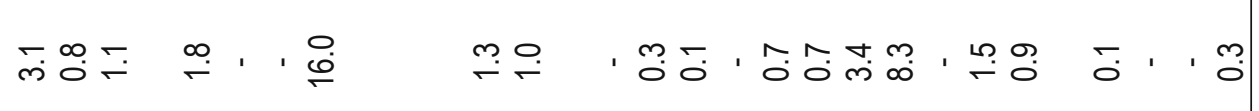

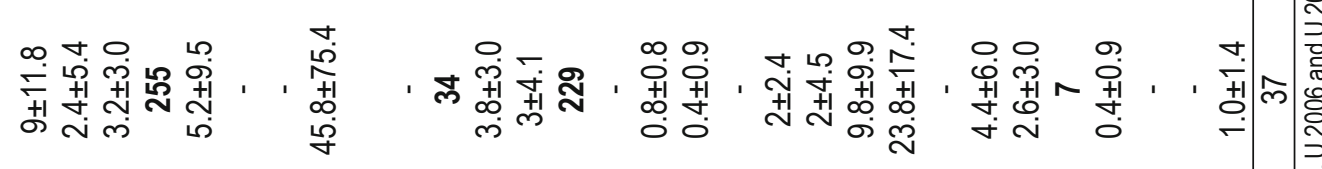
nha hana m mom

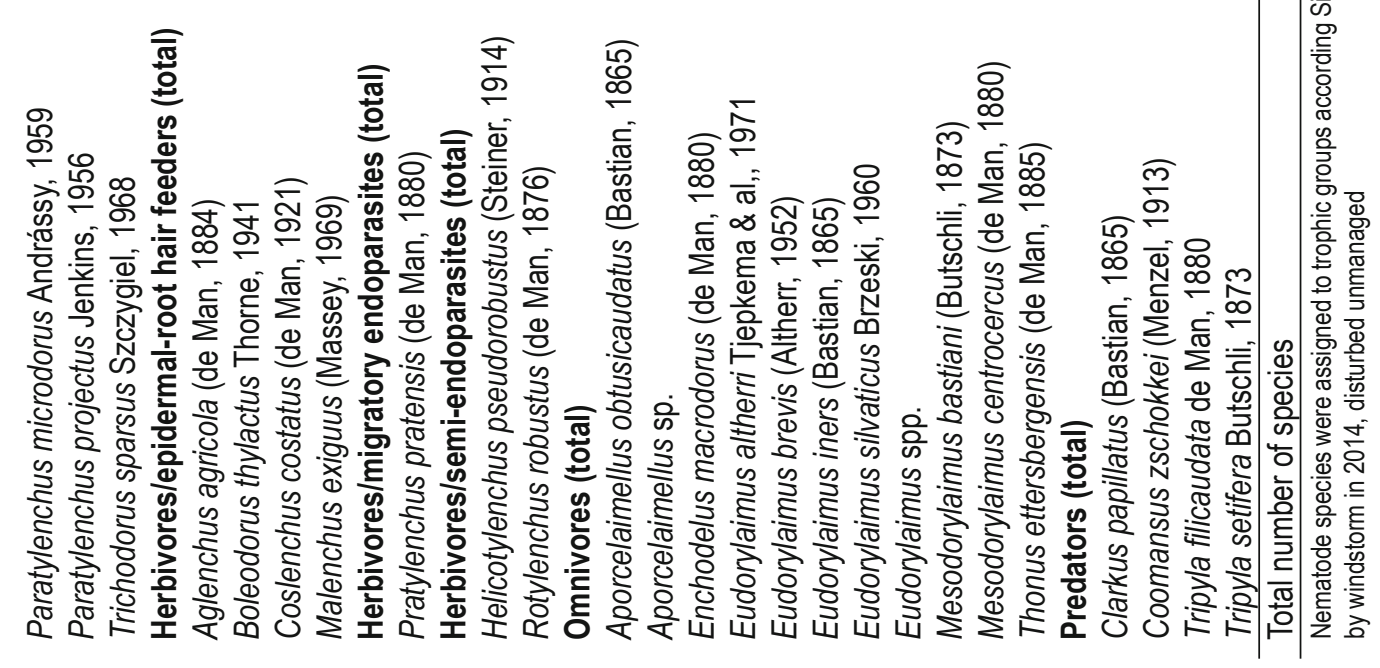


The all extracted nematodes were microscopically identified to the species level (juveniles to genus) based on their morphological markers and morphometries with assistance of original species description and identification keys Andrássy (2005, 2007, 2009), Geraert (2008, 2010), Loof (1999) and others. The Eclipse 90i Nikon, Japan light microscope at 100, 200, 400, 600, and 1000 magnification has been used.

\section{Nematode community and data analysis}

Identified nematode species were allocated to eight trophic groups based on their feeding habits as recommended by Yeates et al. (1993) and Wasilewska (1997). Than adjusted and supplemented according Srieriebriennikov et al. (2014): bacterivores (B), fungivores $(F)$, herbivores/ectoparasites (Hect); herbivores/epidermal root hair feeders (Hroot); herbivores/migratory endoparasites (Hmig); herbivores/semi-endoparasites (Hsem); predators $(P)$ and omnivores (O). Number of species, nematode abundance, mean number of nematodes per trophic group and the Shannon-Weaver index of species diversity were determined. The Shannon-Weaver index of species diversity (H'spp.) was calculated as:

H'spp. $=-\sum P_{i} \times \ln P_{i}$, where $P_{i}$ is the proportion of individuals of the ith taxon (Shannon \& Weaver, 1949)

\section{Ecological and functional indices}

Basic ecological and functional indices were used to assess the status of the soil ecosystem using the nematode communities. The Maturity Index for free-living taxa, $\left.\mathrm{MI}=\sum\left[v_{i} \times f_{i}\right)\right] / n$, where $v_{i}$ is the colonizer-persister (c-p) value of taxon $i, f_{i}$ is the frequency of taxon $i$ in a sample and $n$ is the total number of individuals in a sample; the Plant Parasite Index (PPI), determined similarly as MI but for plant parasitic taxa (Yeates et al., 1993); the Maturity Index 2-5 (MI2-5) (Bongers \& Korthals, 1993), determined similarly as MI but excludes the $c-p 1$ enrichment opportunists and the sigma Maturity Index ( $\Sigma \mathrm{MI})$, determined for all taxa (Yeates, 1994). All maturity indices were calculated using a $c-p$ value that represented the life-history characteristics of the nematode taxa associated with r- and K-selection (Bongers, 1990). To evaluate food web characteristics, Enrichment Index (EI), Structure Index (SI), and Channel Index (Cl) were calculated according the Ferris et al. (2001).

Finally, functional metabolic footprints were calculated. Metabolic footprints provide metrics for the magnitudes of ecosystem functions and services provided by component organisms of the soil food web (Ferris, 2010). All indices and metabolic footprints were calculated with the NINJA online program (Srieriebriennikov et al., 2014) (http:// spark.rstudio.com/bsierieb/ninja; accessed 21 July 2014).

\section{Statistical analysis}

Relative population densities of nematodes in each trophic group were calculated as means for the individual sampling dates. Data were statistically analysed after transformation in arcsen root square values by ANOVA and compared by Least Significant Differences (LSD). Total abundance, the species diversity index (H'spp.) and the data of ecological and functional indices were analysed by analyses of variance (ANOVA), and then compared by the Least Significant Differences (LSD) test of the Plotlt 3.2 program.

Table 2. A comparison of means of nematode abundance, diversity index for species H'spp. and selected nematode community indices in the investigated forest plot in the High Tatra Mountains in October 2006, 2013 and 2014

\begin{tabular}{lccccccc}
\hline Index name & $U 2006$ & & $U 2013$ & & D 2014 & & ANOVA. $p$ \\
\hline Abundance & $287.3 \pm 151.6$ & $\mathrm{a}$ & $489.4 \pm 164.8$ & $\mathrm{a}$ & $675.2 \pm 212.3$ & $\mathrm{~b}$ & $\mathbf{0 . 0 1 6}$ \\
H'spp. & $2.43 \pm 0.34$ & $\mathrm{a}$ & $2.82 \pm 0.13$ & $\mathrm{~b}$ & $2.45 \pm 0.14$ & $\mathrm{a}$ & $\mathbf{0 . 0 2 4}$ \\
Maturity Index & $2.69 \pm 0.39$ & $\mathrm{a}$ & $2.50 \pm 0.16$ & $\mathrm{a}$ & $2.10 \pm 0.07$ & $\mathrm{~b}$ & $\mathbf{0 . 0 0 8}$ \\
Maturity Index 2-5 & $2.80 \pm 0.35$ & $\mathrm{a}$ & $2.66 \pm 0.25$ & $\mathrm{a}$ & $2.17 \pm 0.05$ & $\mathrm{~b}$ & $\mathbf{0 . 0 0 4}$ \\
Sigma Maturity Index & $2.57 \pm 0.24$ & $\mathrm{a}$ & $2.44 \pm 0.10$ & $\mathrm{a}$ & $2.13 \pm 0.06$ & $\mathrm{~b}$ & $\mathbf{0 . 0 0 2}$ \\
Plant Parasitic Index & $2.47 \pm 0.37$ & $\mathrm{a}$ & $2.23 \pm 0.26$ & $\mathrm{a}$ & $2.42 \pm 0.25$ & $\mathrm{a}$ & 0.467 \\
Channel Index & $40.6 \pm 31.5$ & $\mathrm{a}$ & $51.5 \pm 25.1$ & $\mathrm{a}$ & $28.0 \pm 7.8$ & $\mathrm{~b}$ & 0.327 \\
Enrichment Index & $44.0 \pm 9.8$ & $\mathrm{a}$ & $52.05 \pm 14.2$ & $\mathrm{a}$ & $27.4 \pm 4.6$ & $\mathrm{~b}$ & $\mathbf{0 . 0 1 1}$ \\
Structure Index & $71.1 \pm 13.7$ & $\mathrm{a}$ & $66.6 \pm 10.4$ & $\mathrm{a}$ & $27.8 \pm 6.1$ & $\mathrm{~b}$ & $<\mathbf{0 . 0 0 1}$ \\
Total Biomass & $1.52 \pm 0.42$ & $\mathrm{a}$ & $0.51 \pm 0.26$ & $\mathrm{a}$ & $0.68 \pm 0.28$ & $\mathrm{a}$ & 0.247 \\
Composite footprint & $300.1 \pm 301.2$ & $\mathrm{a}$ & $138.7 \pm 57.1$ & $\mathrm{a}$ & $178.8 \pm 63.4$ & $\mathrm{a}$ & 0.370 \\
Enrichment footprint & $242.3 \pm 287.7$ & $\mathrm{a}$ & $65.8 \pm 44.7$ & $\mathrm{a}$ & $91.6 \pm 50.9$ & $\mathrm{a}$ & 0.250 \\
Structure footprint & $38.2 \pm 20.7$ & $\mathrm{a}$ & $40.9 \pm 21.4$ & $\mathrm{a}$ & $20.2 \pm 5.4$ & $\mathrm{a}$ & 0.167 \\
Herbivore footprint & $5.8 \pm 1.3$ & $\mathrm{a}$ & $15.6 \pm 7.4$ & $\mathrm{a}$ & $7.6 \pm 3.9$ & $\mathrm{a}$ & 0.154 \\
Fungivore footprint & $7.1 \pm 5.0$ & $\mathrm{a}$ & $15.7 \pm 7.5$ & $\mathrm{~b}$ & $7.2 \pm 1.8$ & $\mathrm{a}$ & $\mathbf{0 . 0 4 2}$ \\
Bacterivore footprint & $254.5 \pm 196.8$ & $\mathrm{a}$ & $75.9 \pm 44.1$ & $\mathrm{a}$ & $147.9 \pm 59.3$ & $\mathrm{a}$ & 0.309 \\
Predator footprint & $0.7 \pm 0.9$ & $\mathrm{a}$ & $6.9 \pm 11.2$ & $\mathrm{a}$ & $2.6 \pm 1.6$ & $\mathrm{a}$ & 0.334 \\
Omnivore footprint & $32.2 \pm 19.9$ & $\mathrm{a}$ & $24.6 \pm 8.8$ & $\mathrm{a}$ & $13.7 \pm 4.7$ & $\mathrm{~b}$ & $\mathbf{0 . 0 1 6}$ \\
\hline
\end{tabular}

Mean values followed by the same letters (a. b. etc.) are not statistically different according to the Least Significant Difference test (P $\geq 0.05)$ $(n=5)$. Selected ecological and functional indices and metabolic footprints were calculated according Sieriebriennikov et al. (2014). U 2006 and U 2013, forest unaffected by windstorm - undisturbed; D 2014, forest affected by windstorm in 2014 - disturbed unmanaged. 


\section{Results}

Nematode community analysis

A total of 7205 individuals, comprising 54 species and 39 genera were identified by this study. The highest number of species in 2013 was found in undisturbed forest and was slightly higher than in disturbed forest in 2014 (Table 1). ANOVA test showed significant differences in nematode abundance between years of soil sampling on the plot $(P=0.016)$ (Table 2). Overall, the nematode abundance was significantly higher in the 2014 disturbed forest in comparison with both sampling dates before the windstorm event (LSD, $P=0.05$ ).

The abundance of nematode species as well as densities of nematode trophic groups was affected by windstorm disaster. Nineteen bacterivorous species, 11 fungal feeders and herbivores, 9 omnivores and 4 predators were found. Overall, the most abundant species in the studied spruce forest stand was Acrobeloides nanus. Windstorm disaster influenced the total number as well as relative densities of nematode trophic groups and the abundance of particular nematode species. Relative density of B nematodes was significantly higher in disturbed (2014) when compared to undisturbed forests (2006 - 2013; Table 3). It was caused by abundance increase in the following species: $A$. nanus, Cephalobus persegnis, Plectus communis, $P$. decens and $P$. parvus (Table 1). In contrast, the density of $F$ nematodes significantly decreased after the event in 2014 (Table 3). This was instigated by declining in abundance or dominance of previously prevalent fungivores species $F$. vulgaris, T. mirabilis, Tylencholaimus minimus, Aphelenchoides composticola and $A$. parietinus (Table 1). The mean Hect and Hroot relative abundances showed a similar pattern (LSD, $P=0.05$ ) (Table 3). The species which prevailed in the 2006 and 2013 (Paratylenchus microdorus, Trichodorus sparsus, M. exiguus, Helicotylenchus pseudorobustus and Rotylenchus robustus), contrary declined in abundance after the windstorm event in 2014 (Table 1).

The mean 0 nematode abundance was also significantly lower after the forest devastation ( $L S D, P=0.05$ ); $O$ nematodes were

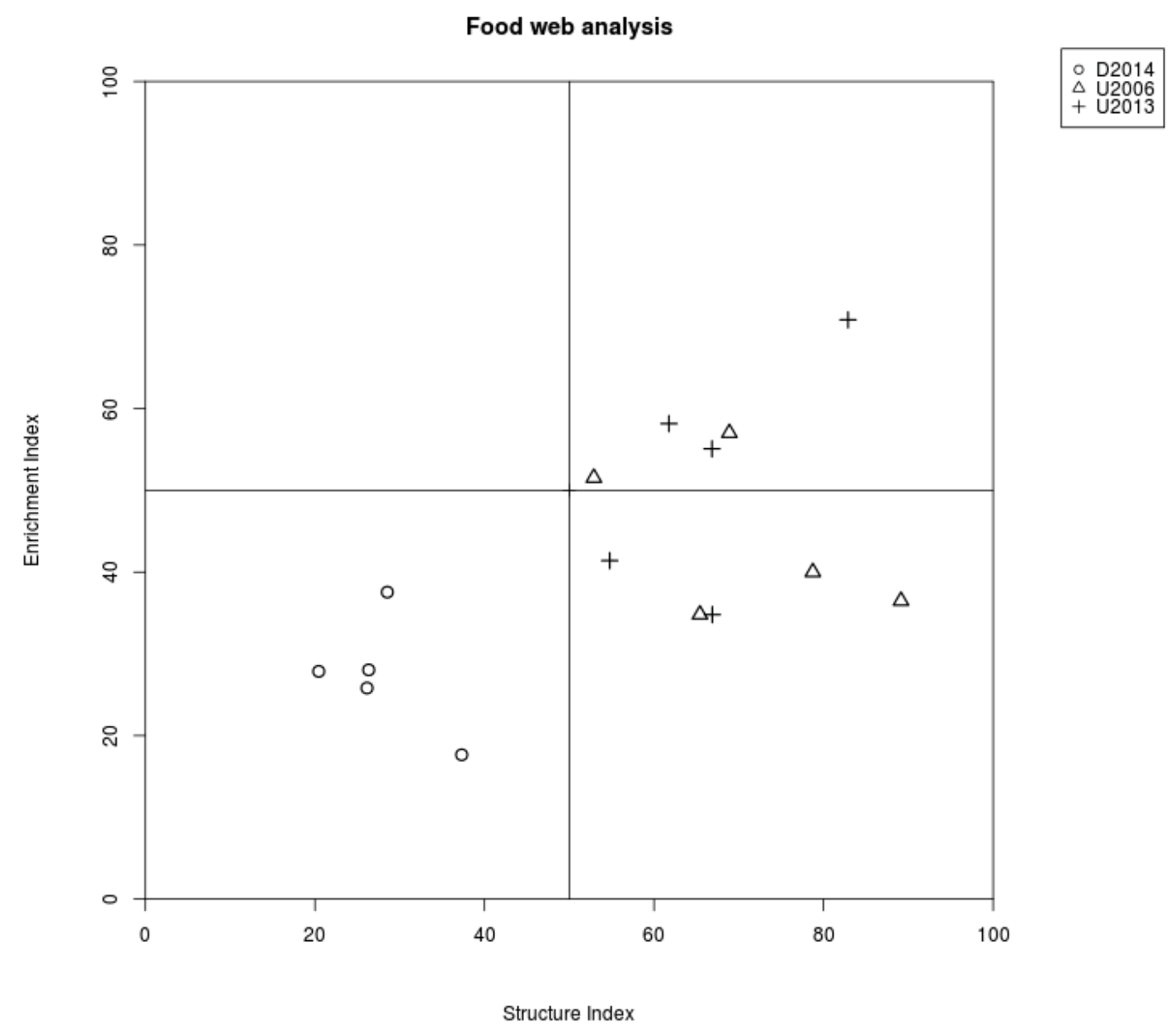

Fig. 1. Diagram of the Enrichment and Structure indices calculated separately for each sampling date in the research plot of spruce forest in the High Tatra Mountains (n=5). U 2006 and U 2013, forest unaffected by windstorm - undisturbed; D 2014, forest affected by windstorm in 2014 - disturbed unmanaged. 
Table 3. Relative abundance (\%) of nematode in trophic groups in the investigated plot of spruce forest in the High Tatra Mountains in October 2006,2013 and 2014.

\begin{tabular}{|c|c|c|c|c|c|c|}
\hline Trophic groups & U 2006 & & U 2013 & & D 2014 & \\
\hline Bacterivores & $35.7 \pm 15.3$ & a & $27.4 \pm 5.8$ & a & $76.5 \pm 6.4$ & $b$ \\
\hline Fungivores & $26.6 \pm 8.7$ & a & $31.1 \pm 7.8$ & a & $11.0 \pm 3.3$ & $\mathrm{~b}$ \\
\hline Predators & $1.0 \pm 1.9$ & a & $4.1 \pm 7.0$ & $b$ & $0.8 \pm 0.5$ & a \\
\hline Omnivores & $15.6 \pm 3.1$ & a & $6.2 \pm 1.2$ & a & $3.3 \pm 0.8$ & $b$ \\
\hline Herbivores migratory endoparasites & $0.0 \pm 0.0$ & a & $0.0 \pm 0.0$ & a & $0.2 \pm 0.4$ & a \\
\hline Herbivores semi-endoparasites & $2.5 \pm 2.3$ & a & $8.3 \pm 1.9$ & $b$ & $3.0 \pm 1.2$ & $b$ \\
\hline Herbivores Ectoparasites & $6.3 \pm 2.5$ & a & $3.7 \pm 1.7$ & a & $0.4 \pm 0.2$ & $\mathrm{~b}$ \\
\hline Herbivores Epidermal/root hair feeders & $12.2 \pm 1.4$ & a & $19.4 \pm 7.4$ & a & $4.9 \pm 2.4$ & $b$ \\
\hline
\end{tabular}

more abundant with the dominance of Eudorylaimus spp. in undisturbed 2006 and 2013 (Table 3) plot. The abundance of $P$ and Hmig nematodes did not differ significantly between examined years (Table 3 ). Total nematode biomass varied inconsistently, but the highest biomass in 2006 was due to the higher abundance of large omnivorous nematodes (Table 2).
Ecological, functional, and diversity indices of nematode communities

Mean values of the community indices and metabolic footprints for the three years are shown on Table 2. H'spp. of the soil-nematode communities differ between years examined. H'spp. was significantly higher in undisturbed stand in 2013 than in disturbed forest

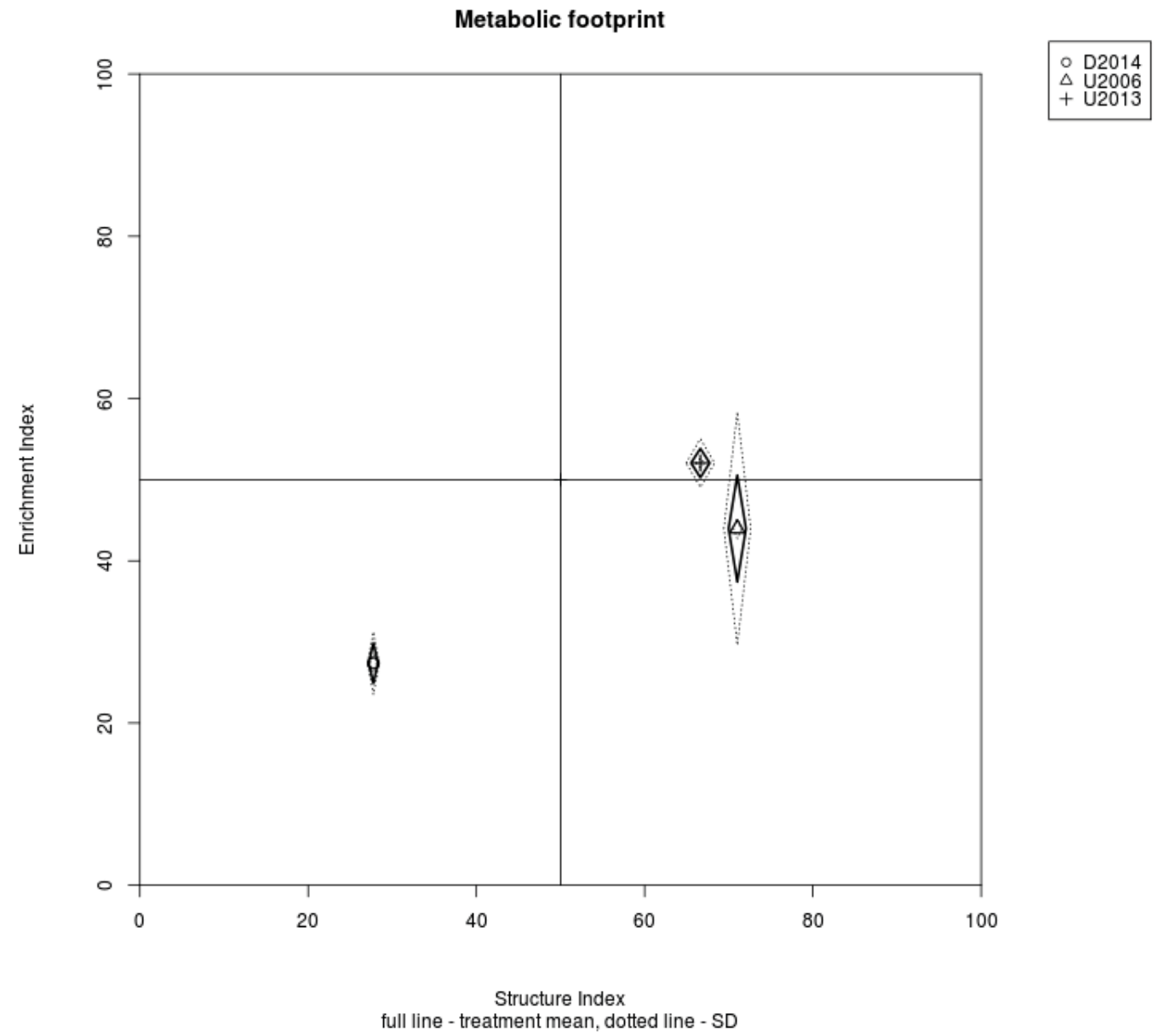

Fig. 2. Metabolic footprints calculated separately for each sampling date in in the research plot of spruce forest in the High Tatra Mountains ( $n=5)$. $U$ 2006 and $U$ 2013, forest unaffected by windstorm - undisturbed; D 2014, forest affected by windstorm in 2014 - disturbed unmanaged. 
from $2014(P<0.024)$ (Table 2). Forest devastation by windstorm significantly influenced all maturity indices (MI, MI2-5 and $\sum \mathrm{MI}$ ). These indices were significantly lower in disturbed forest from 2014 than in undisturbed forest in 2006 and 2013 without significant difference between years 2006 and 2013 (Table 2).

The Channel Index $(\mathrm{Cl})$, which indicates the predominant decomposition channel in the soil food web, did not differ between the sampling dates (Table 2). The Enrichment Index (EI), which characterizes the intensity of nutrient enrichment (high El) or depletion (low El) was always significantly higher in undisturbed forests in 2006 and 2013 when compared with disturbed forest in 2014 (ANOVA, $P=0.011$ ). The Structure Index (SI) which indicates if the soil ecosystem is structured with stronger (high SI) or degraded (low SI) trophic links, was also significantly higher in 2006 and 2013 than after forest destruction in 2014 (ANOVA, $P=<0.001$ ) (Table 2). The Enrichment Index and the Structure Index, separated all the samples collected in undisturbed forest in 2006 and 2013 to quadrant " $\mathrm{B}$ " and " $\mathrm{C}$ " characterizing the soil environment as maturing and structured, fertile, having low to moderate damage, $\mathrm{N}$-rich, and with a low or moderate C:N ratio (Fig. 1). In contrast, all of the samples collected after forest damage in 2014 were assigned to quadrant "D", characterizing the soil environment as degraded, stressed, nutrient depleted and with a high C:N ratio (Fig. 1). This finding corresponded with the metabolic footprints characteristics of the soil food web which is displayed graphically in Fig. 2. The soil samples collected in plot before the forest devastation by windstorm $(2006,2013)$ were located in quadrant "B" and " $C$ ", whereas the nematode community in soil samples collected after windstorm was clustered in quadrant "D". Moreover, soil ecosystem before windstorm was more metabolically balanced in undisturbed 2013 (illustrated area had a square shape) when compared with undisturbed plot from 2006 (rhomboid shape; Fig. 2). The order of the values of nematode metabolic footprints was bacteriovores $>$ fungivores $>$ herbivores $>$ omnivores $>$ predators. Nevertheless, only the values from fungivore footprint and omnivore footprint significantly differed between sampling dates (Table 2).

\section{Discussion}

Since November 2004 when large windstorm destroyed thousands hectares of Norway spruce forests in High Tatras National Park, many studies have been conducted to elucidate the storm impact on changes of all ecosystem components including soil organisms (Fleisher \& Homolová, 2011). Our previous study (Čerevková \& Renčo, 2009; Čerevková et al., 2013), showed that the windstorm did not negatively affected nematode abundance. The higher nematode abundance may be attributed to the secondary plant succession and changes in the herbaceous cover, which can directly or indirectly affect food sources for different nematode trophic groups. Such changes in plant communities occurred the first year after the 2004 windstorm (Šoltés et al., 2010) and appeared also in our research plot, few months after its destruction by storm in 2014
(Homolová et al., 2015). The heliophilous grass C. villosa and the acidophilous grass $A$. flexuosa rapidly colonized damaged area after the 2004 storm (Šoltés et al., 2010) and have remained dominant in damaged plots (Renčo et al., 2015). These species are good indicators regarding its availability to light and water (Šoltés et al., 2010) and consistent with the findings of Magnusson (1983) and Háněl (1993) who found dominance of grasses such as $C$. villosa, $A$. flexuosa or $C$. arundinacea in spruce forests after the clearings or destruction by industrial emissions during early stages of reforestation.

Overall, the total number of species recorded in spruce forest of High Tatras Mountains (54) corresponds with records of Ruess (1995) from spruce forests in Germany $(33$ - 65) or Háněl (1996, 2004) from spruce forests in the Czech Republic $(54-74)$. All these spruce forests have extremely acidified soils with $\mathrm{pH}$ range from 2.9 to 4.5 . Thus, we can consider this nematode species numbers as typical for acid soils of European spruce forests. In contrast, Querceto-Fageto-Aceretum deciduous forest soils with pH 7.0 - 7.7 in the PLA Vihorlat (Slovakia) reached number of nematode species up 68 to 167 (Háněl \& Čerevková, 2010). The number of nematode species in our study slightly decreased after the windstorm, but not significantly.

The distribution of nematode trophic groups in the research plot before its destruction by 2014 windstorm was typical for European natural coniferous forests with prevalence of $B$ and $F$, followed by Hroot and $\mathrm{O}$ nematodes with relatively low proportion of $\mathrm{P}$ nematodes. However, the forest devastation by windstorm in May 2014 caused significant changes in relative densities of these nematode trophic groups, with the exception for $P$ nematodes. While, $B$ nematodes significantly increased and double the abundance recorded before event; $\mathrm{F}, \mathrm{O}$ and Hroot nematodes significantly declined. Bacterivorous nematodes are often the most dominant trophic group in forests (Räty \& Huhta, 2003; Lišková et al., 2008; Renčo et al., 2012; Zhang, 2015) and their abundance and proportion in the nematode community can increase after ecosystem disturbance (Háněl, 2004; Sohlenius 2002; Šalamún et al., 2014; Renčo \& Baležentiené, 2015; Liu et al., 2015). According to Wasilewska (1998) bacterivorous soil nematodes are linked with the decomposition of organic matter through their feeding on saprophytic microbes. Increased abundance in this group attests to an abundance of easily-decomposable organic matter, be this of plant origin (grasses). As shown by our long-term study (Renčo et al., 2015) the significantly higher abundance of $B$ in storm affected sites persists even nine years after the disaster. It suggests a prolonged availability of readily decomposing organic matter and enhanced microbiological activity. Thus this confirms data from longterm analysis $(2006-2013)$ of soil microbial communities after the 2004 windstorm (Gömöryová et al., 2014) as well as data recorded in our research plot after the 2014 storm (Gömöryová, unpublished data). She recorded significant increase in richness and diversity of microbial community what resulted in increase of basal respiration and microbial biomass $C$ five months after the 2014 event 
when compared to data recorded from undisturbed plot in 2013. In contrast, (Brzeski, 1993) recorded rapid increase of bacteria and consequently abundance of $B$ nematodes after green manure, but the effect of amendments on B nematodes was short timed and population has declined, six months after fertilisation.

The most dominant nematode species in researched plot in High Tatras, with rapid increasing abundance after forest devastation by windstorm, was bacterivore $A$. nanus, confirming our previous records (Čerevková \& Renčo, 2009) and the other reports from Czech Republic (Háněl 1993, 1996, 1999, 2004), Germany (Ruess, 1995) or Sweden (Sohlenius \& Boström, 2001) where high abundance of genus Acrobeloides in vital spruce or pine forests with low soil $\mathrm{pH}$ was found. We can therefore consider the nematodes of this genus as ecological indicator of acidic soil condition for European coniferous forests.

In our study, fungivores were the second most abundant trophic group in forest soil before $(2006,2013)$ but also after the forest devastation in 2014. However their relative density significantly decreased after forest damage compared with time before event. According to Wasilewska (1997) fungivores are strongly associated with soil pH level and thus provide good indicator for changes of this characteristic soil. An increase in abundance of FFs, or as a proportion of the total nematode community, provides information about increasing soil acidity (Reuss, 1995; Ruess et al., 1996; Sohlenius \& Wasilewska, 1984). Since the soil acidity remained unaffected five months after the event (Gömöryová, unpublished data) decline in the proportion of $\mathrm{F}$ in the nematode community could be attributed to the dramatic increase of abundance for BFs. Predators and omnivores comprising K-selected nematode species (Bongers, 1990) are regarded as bioindicators of environmental perturbance having long-life cycles, low reproduction rate and low colonization ability. Our ten-year research in the research plots in High Tatras spruce forests affected by two windstorms showed that predators in general have relatively low abundance in this ecosystem what complicates their use as bio-indicators of spruce forest devastation as presented in previous studies (Háněl, 2004). Overall, the predators have very low numbers or absent in acidic coniferous soils throughout the Europe (Ruess, 1995; Háněl, 1996, 1999, 2004; Sohlenius \& Boström 2001; Bassus, 1962) what was confirmed also by observation of Ruess et al., (1996) where acid precipitation significantly decreased number of predators in spruce forests. In contrary, Mladenov et al. (2004) found in urban Querceto-Fraxinus forest in Bulgaria, with soil pH 6.5, much higher predators abundance.

Quite the opposite, in our study omnivores had relatively high abundance in the nematode community before forest damage, but have been found very sensitive to the ecosystem deterioration. Mainly Eudorylaimus spp.; they rapidly fall in abundance, consistent with the data from clear-cut spruce forests in short-term study (Háněl \& Čerevková, 2010) or after clear-cutting of spruce trees that died of bark beetle attack (Háněl, 2004). Although contradicting with our previous findings, when the abundance of $O$ nematodes did not differ between control and windstorm disturbed plots (Čerevková et al., 2013). A causal explanation for this contradiction could be that destruction of spruce forests by two windstorms occurred in different period of year 2004 or 2014, respectively. The 2004 windstorm formed in November 19 (late autumn) when soil was frozen with snow covering the land. Therefore soil fauna hibernating and abundance of sensitive nematode taxa of omnivores were thus not directly affected by the disaster. In contrast, the storm in 2014 happened in May 15 when soil inhabitant have been continuing their live cycles, so ecosystem deterioration could affect development of sensitive omnivorous species, which did not recover until our soil sampling in October 2014.

Nematode community structure can be determined by many ways. The abundance of each species in a community as descriptive indicator can be transformed into ecological indices and parameters as evaluative indicators, by measuring changes in the diversity and trophic structure of the community and by assessing the levels of soil disturbance and decomposition pathways (Bongers, 1990; Heink \& Kowarik, 2010). Maturity indices can represent the degree of environmental disturbance, with lower values indicating a more disturbed and enriched environment and higher values indicating a less disturbed and steadier environment (Bongers, 1990). In our study, all maturity indices (MI, MI2-5, $\Sigma \mathrm{MI}$ ) were significantly lower five month after the 2014 windstorm, when compared with data recorded before that event. Thus confirming our previous findings (Čerevková et al., 2013) and those recorded by other researchers (Bjørnlund et al., 2002; Forge \& Simard, 2001). However, time may be a positive factor for the rehabilitation of soil-nematode communities, because neither Maturity Index (Ml or $\sum \mathrm{MI}$ ) differed significantly between the damaged and undamaged spruce forest plots in the High Tatras Mts. nine years after the 2004 windstorm (Renčo et al., 2015).

SI and El provide strong interpretative tool for the assessment of environmental disturbances (Ferris et al., 2001). Our analysis of the functional guilds in forest plot before and after its devastation by 2014 windstorm indicated significant differences in both $\mathrm{El}$ and SI. The disturbed forest plot in 2014 had lower Els and Sls than undisturbed in 2006 and 2013. It suggests that the soil ecosystem five months after windstorm is nutrient depleted with degraded trophic links (Ferris et al., 2001). These findings corresponded with our previous recorded within first three years after the 2004 windstorm (Čerevková \& Renčo, 2009). Time has been found as positive factor for nutrient and trophic links recovery (Renčo et al., 2015). The order of values of nematode metabolic footprints was bacterivores $>$ fungivores $>$ herbivores that revealed bacterial-based energy channel in High Tatra spruce forest confirmed results and conclusions of Ciobanu et al. (2015) from analyses of soil samples collected in the Romanian coniferous forests.

\section{Conclusion}

Natural catastrophes are natural events occurring in every ecosystem. However, it cannot be predicted where and which ecosystems will be exposed to the natural disturbance agents in or- 
der to collect relevant data as valuable indicators (fauna, flora) before event. Therefore, the destruction of spruce forest by 2014 windstorm what included the site that has been monitored since 2004 windstorm as a control plot provided an ideal opportunity to follow up a direct impact of storm to changes within soil nematode communities. We conclude that the total nematode abundance increased, species diversity decreased but total number of nematode species remained similar after the event. Total number and relative population density of bacterivorous nematodes increased; fungivores, omnivores and herbivores decreased after the windstorm. Low abundance of predators in the High Tatras acidic spruce forest soils complicate their use as bio-indicators for the ecosystem disturbance. The low values of all maturity indices indicated the existence of not mature nematode assemblages. The weighted faunal analysis also suggests that windstorm disturbed the forest soil nematode communities. These results supported the role of nematode communities as potential indicators of environmental conditions and its disruption.

\section{Acknowledgement}

The authors acknowledge the support of the scientific grant agency VEGA, project no. 2/0013/16 (0.5) and project "Application Centre to protect humans, animals and plants against parasites" (Code ITMS: 26220220018) supported by the Operational Programme "Research and Development funded from the European Regional Development Found (0.5).

\section{References}

ANDRÁSSY, I. (2005): Free-living nematodes of Hungary (Nematoda errantia), Volume I. Budapest, Hungarian Natural History Museum and Systematic Zoology Research Group of the Hungarian Academy of Sciences

ANDRÁSSY, I. (2007): Free-living nematodes of Hungary (Nematoda errantia), Volume II. Budapest, Hungarian Natural History Museum and Systematic Zoology Research Group of the Hungarian Academy of Sciences

ANDRÁSSY, I. (2009): Free-living nematodes of Hungary (Nematoda errantia), Volume III. Budapest, Hungarian Natural History Museum and Systematic Zoology Research Group of the Hungarian Academy of Sciences

BAssus, W. (1962): Untersuchungen uber die Nematodenfauna mitteldeutscher Waldboden. Wiss Z Humboldt-Univ Berlin MathNat R 11, 145 - 177

Bjørnlund, L., Vestergård, M., Johansson, S., Nyborg, M., Steffensen, L., Christensen, S. (2002): Nematode communities of natural and managed beech forests - a pilot survey. Pedobiologia, 46: 53 - 62. DOI:10.1078/0031-4056-00113

Bongers, T. (1990): The maturity index: an ecological measure of environmental disturbance based on nematode species composition. Oecologia 83:14 - 19. DOI: 10.1007/BF00324627
Bongers, T., Korthals, G. (1993): The Maturity Index, an instrument to monitor changes in the nematode community structure. Summaries of the $45^{\text {th }}$ International Symposium on Crop Protection, May 4, Gent, Belgium, pp. 80

Brzeski, M.W., Smolińska, M., Szczech, M., Paul, P., Ostrzycka, J. (1993): Short term effect of green manuring on soil inhabiting nematodes and microorganisms. Nematol. Medit., 21: 169 - 176 Ciobanu, M., Popovici, I., Zhao, J., \& Stolca, I. A. (2015): Patterns of relative magnitudes of soil energy channels and their relationships with environmental factors in different ecosystems in Romania. Scientific reports, 5

CoвB, N.A. (1918): Estimating the nematode population of the soil. Agric. Tech. Circ. Bur. PI. Ind., US Dep Agric No.1 48 pp

Č́erevková, A., Renčo, M. (2009): Soil nematode community changes associated with windfall and wildfire in forest soil at the High Tatras National Park, Slovak Republic. Helminthologia, 46: 123 - 130. DOI: 10.2478/s11687-009-0024-9

Č́erevková, A., RenČo, M., CAgÁŇ, L'. (2013): Short-term effects of forest disturbances on soil nematode communities in European mountain spruce forests. J. Helminth. 87: 376 - 185. DOI: 10.1017/S0022149X12000508

Doran, J.W., ZeISS, M.R. (2000): Soil health and sustainability: managing the biotic component of soil quality. Appl. Soil. Ecol. 15:3 - 11. DOI: 10.1016/S0929-1393(00)00067-6

EverHAM, E.M., BROKAW, N.V. (1996): Forest damage and recovery from catastrophic wind. Bot. Rew., 62: 113 - 185. DOI: 10.1007/ BF02857920

FERRIS, H. (2010): Form and function: Metabolic footprints in the nematodes soil food web. Eur. J. Soil Biol., 46:97 - 104. DOl: 10.1016/j.ejsobi.2010.01.003

Ferris, H., Bongers, T., de Goede, R.G.M. (2001): A framework for soil food web diagnostics: extension of the nematode faunal analysis concept. Appl. Soil Ecol., 18:13 - 29. DOI: 10.1016/S09291393(01)00152-4

FLEISCHER, P. (2008): Windfall research and monitoring in the High Tatra Mts., objectives, principles, methods, and current status. Contrib. Geoph. Geod. 38: 233 - 248

Fleischer, P., Homoloví, Z. (2011): Studies on High Tatra National Park, Ecological consequences of windstorm 2004 on the High Tatra Mts. nature - monography, 10(43)

Forge, T., SimARD, S. (2001): Structure of nematode communities in forest soils of southern British Columbia: relationships to nitrogen mineralization and effects of clear-cut harvesting and fertilization. Biol. Fert. Soils, 34: 170 - 178. DOI: 10.1007/ s003740100390

GERAERT, E. (2008): The Tylenchidae of the world. Identification of the family Tylenchidae (Nematoda). Academia Press, Gent, 540 pp. Geraert, E. (2010): The Criconematidae of the world. Identification of the family Criconematidae (Nematoda). Academia Press, Gent, $615 \mathrm{pp}$.

Gömöryová, E., Fleischer, P., Gömöry, D. (2014): Soil microbial community responses to windthrow disturbance in Tatra National 
Park (Slovakia) during the period 2006 - 2013. Forestry J., 60: 137 - 142. DOI: 10.2478/forj-2014-0014

Gubka, A., Kunca, A., Longauerová, V., Malová, M., Vakula, J., Galko, J., NiKolov, Ch., Rell, S., ZúBriK, M., Leontovyč, R. (2014): Vetrová kalamita Žofia z 15.5.2014 [Windthrow Žofia from May 15, 2014]. Usmernenie lesníckej ochranárskej služby, 8: 1 - 8 (In Slovak)

HÁnĚL, L. (1993): Soil nematodes (Nematoda) in Norway spruce forests of the Krušné hory Mts. injured by immissions. Lesníctví-Forestry, 39:365 - 369

HÁnĚL, L. (1996): Soil nematodes of five spruce forests of the Beskydy mountains, Czech Republic. Fund. Appl. Nematol., 19: $15-24$

HÁnĚL, L. (1999): Fauna of soil nematodes (Nematoda) in Trojmezná hora Reserve. Silva Gabreta, 3: 89 - 94

HÁnĚL, L. (2004): Response of soil nematodes inhabiting spruce forests in the Šumava Mountains to disturbance by bark beetles and clear-cutting. Forest Ecol. Manag., 202: 209 - 225. DOI: 10.1016/j.foreco.2004.07.027

HÁnĚL, L., ČerevkovÁ, A. (2010): Species and genera of soil nematodes in forest ecosystems of the Vihorlat Protected Landscape Area, Slovakia. Helminthologia, 47: 123 - 135. DOI: 10.2478/ s11687-010-0019-6

HeINK, U., KoWARIK, I. (2010): What are indicators? On the definition of indicators in ecology and environmental planning. Ecol. Indicators, 10: 584 - 593. DOI: 10.1016/j.ecolind.2009.09.009

Homolová, Z., Kyselová, Z., Šoltés, R. (2015): Dynamics of vegetation community Lariceto-Piceetum in calamity area. Studies on Tatra National Park, 11:183 - 191

LINDENMAYER, B.D. (1999): Future directions for biodiversity conservation in managed forests: indicator species, impact studies and monitoring programs. Forest Ecol. Manag., 115: 277 - 287. DOI: 10.1016/S0378-1127(98)00406-X

LišKovÁ, M., Čerevková, A., HÁnĚL, L. (2008): Nematode communities of forest ecosystems in association with various soil orders. Russian J. Nematol. ,16: 129 - 142

LIU, Y.B., ZHANG, L.L., LIU, Q.Z. (2015): Changes of nematode community under monoculture wheat and wheat/jujube intercropping system in Xinjiang, Northwest China. Helminthologia, 52: 123 129. DOI: $10.1515 /$ helmin-2015-0022

Loof, P.A.A. (1999): Nematoda: Adenophorea (Dorylaimida). Heidelberg, Berlin, Spektrum Akademischer Verlag, 264 pp.

Magnusson, CH. (1983): Abundance, distribution and feeding relations of root/fungal feeding nematodes in a Scots pine forest. Holarc. Ecol., 6: 183 - 193

Mladenov, A., Lazarova, S., Peneva, V. (2004): Distribution patterns of nematode communities in an urban forest in Sofia, Bulgaria. In: Penev, L., Niemela, J., Kotze, D., Chipev, N. (Eds) Ecology of the city of Sofia: species and communities in an urban environment. Pensoft Publishers, Sofia, p. 456

Neher, D.A., Wu, J., Barbercheck, M.E., Anas, O. (2005): Ecosystem type affects interpretation of soil nematode community measures.
Appl. Soil Ecol., 30: 47 - 64. DOI: 10.1016/j.apsoil.2005.01.002 RäTY, M., HUHTA, V. (2003): Nematode communities of anthropogenous birch stands in central Finland. Nematology, 5: 629 - 639 DOI: $10.1163 / 156854103322683346$

Renčo, M., BaležentienÉ, L. (2015): An analysis of soil free-living and plant-parasitic nematode communities in three habitats invaded by Heracleum sosnowskyi in central Lithuania. Biol. Invasions, 17: 1025 - 1039. DOI: 10.1007/s10530-014-0773-3

Renčo, M., Čerevková, A., Homolová, Z., Gömöryová, E. (2015): Longterm effects on soil nematode community structure in spruce forests of removing or not removing fallen trees after a windstorm. Forest Ecol. Manag., 356: 243 - 252. DOI: 10.1016/ j.foreco.2015.07.008

Renčo, M., Čermák, V., Čerevková, A. (2012): Composition of soil nematode communities in native birch forests in Central Europe. Nematology, 14: 15 - 25. DOI: 10.1163/138855411X575430

RuESS, L. (1995): Nematode fauna in spruce forest soils: a qualitative/quantitative comparison. Nematologica, 41:106 - 124. DOI: 10.1163/003925995X00080

Ruess, L., DIGHTON J. (1996): Cultural studies on soil nematodes and their fungal hosts. Nematologica, 42: 330 - 346. DOI: 10.1163/004425996X00065

Ruess, L., Sandbach, P., Cudlin, P., Dighton, J., Crossley, A. (1996): Acid deposition in a spruce forest soil: effects on nematodes, mycorrhizas and fungal biomass. Pedobiologia, 40: $51-66$ SEINHORST, J.W. (1962): On the killing, fixation and transferring to glycerine of nematodes. Nematologica, 8: 29 - 32

Shannon, C.E., Weaver, W. (1949): The mathematical theory of communication. University of Illinois Press, Urbana

Sieriebriennikov, B., Ferris, H., de Goede, R.G.M. (2014): NINJA: An automated calculation system for nematode-based biological monitoring. Eur. J. Soil. Biol. 61: 90 - 93. DOI: 10.1016/j.ejsobi.2014.02.004

SoHLENIUS, B. (2002): Influence of clear-cutting and forest age on the nematode fauna in a Swedish pine forest soil. Appl. Soil Ecol., 19: 261 - 277. DOI: 10.1016/S0929-1393(02)00003-3

Sohlenius, B., Boström, S. (2001): Annual and long-term fluctuations of the nematode fauna in a Swedish Scots pine forest soil. Pedobiologia, 45: 408 - 429. DOI: 10.1078/0031-4056-00096

SOHLENIUS, B., WASILEWSKA, L. (1984): Influence of irrigation and fertilization on the nematode community in a Swedish pine forest soil. J. Appl. Ecol., 32: 327 - 342. DOI: 10.2307/2403057

Šalamún, P., Kucanová, E., Brázová, T., Miklisová, D., Renčo, M., HanzelovÁ, V. (2014): Diversity and food web structure of nematode communities under high soil salinity and alkaline $\mathrm{pH}$. Ecotoxicology, 23: 1367-1376. DOl:10.1007/s10646

Šoltés, R., ŠKolek, J., Homolová, Z., KyselovÁ, Z. (2010): Early succession pathways in the Tatra Mountains (Slovakia) forest ecosystems following natural disturbances. Biologia (Bratislava) 65: 958 - 964. DOI: 10.2478/s11756-010-0110-y

van Benzoljen, J. (2006): Methods and techniques for nematology. Wagenningen University, 112 pp

WASILEWSKA, L. (1997): Soil invertebrates as bioindicators, with 
special reference to soil-inhabiting nematodes. Russ. J. Nematol., 5: $113-126$

WASILEWSKA, L. (1998): Changes in the proportions of groups of bacteriovorous soil nematodes with different life strategies in relation to environmental conditions. Appl. Soil Ecol., 9: 215 - 220. DOI: 10.1016/S0929-1393(98)00078-X

YEATES, G.W. (1994): Modification and qualification of the Nematode Maturity Index. Pedobiologia, 38: 97 - 101

Yeates, G.W., Bongers, T., de Goede, R.G.M., Freckman, D.W., GEORGIEVA, S.S. (1993): Feeding habits in soil nematode families and genera: an outline for soil ecologists. J. Nematol., 25: 315-331 Yeates, G.W., Hawke, M.F., RiJkse, W.C. (2000): Changes in soil fauna and soil conditions under Pinus radiata agroforestry regimes during a 25-year tree rotation. Biol. Fertil. Soils, 31: 391 - 406. DOI: $10.1007 / \mathrm{s} 003749900186$

ZHANG, X. (2015): Community composition, diversity and metabolic footprints of soil nematodes in differently-aged temperate forests. Soil Biol. Biochem., 80: 118 - 126. DOI: 10.1016/j.soilbio.2014.10.003 